\title{
GLL
}

00

\section{HISTORICAL LAND USE CONVERSION IN KRAKÓW'S METROPOLITAN ZONE}

\author{
Barbara Prus, Arkadiusz Nowak
}

\section{Summary}

Land use conversion is a dynamic process that occurs all over the world. The scale of this process is global, and depends on related driving forces. There are numerous case studies of land use changes but only a few synthesise the results.

The aim of the study is to analyse historical land use conversions in two villages located in periurban areas of the city of Kraków, and in particular, to indicate the directions of these changes associated with the distance of the given village to Kraków. The examples of two villages were selected so as to indicate the direction of changes in the immediate vicinity of the city as well as in a zone further outside the city. The aim is also to present a possible approach to monitoring the long-term development of these areas.

As regards Poland, the expansion of urban pattern of land development outside the administrative boundaries of cities results in direct interference in agricultural production space, and not infrequently in areas having particular natural and cultural values. This is also the case within the zone of the direct impact of the city of Kraków on areas located to the south of the urban agglomeration. The article confirms that the changes involve the conversion of agricultural areas into built-up and urbanised areas. Nevertheless, the study results indicate an unexpected increase in the area of wasteland in close vicinity of the city, despite soil conditions being favourable to pursuing agricultural activities. It is a long-term study, which considers precise maps showing land use structure. It is the first step towards designing multi-scale studies that would consider land use changes in the neighbourhood of metropolitan areas.

\section{Keywords}

land use changes - metropolitan areas - suburbanisation - agricultural marginalisation - historical GIS

\section{Introduction}

Land uses change because they are the result of consecutive reorganisation of the land in order to adapt it to the changing societal demands [Antrop 2005]. In a recent study on land use conversion in a more urbanised part of Poland, we can consider three main trends of the illustrated changes, which are: urbanisation, agriculture changes, and greening [Hersperger and Bürgi 2009, Seto et al. 2011, van Vliet et al. 2015]. Different trends 
of land use changes are varying in different regions, which results from both the natural environment and the anthropogenic determinants [Lambin and Geist 2006, Robinson et al. 2014]. The nature and the cultural heritage of the region are threatened by recent social and economic transformations, which have triggered widespread land use changes. This is particularly the case in the location where two policies clash - namely, biodiversity protection and the expansive urbanisation process [van Asselen et al. 2013].

Studies into and analyses of land uses in the first half of the $19^{\text {th }}$ century indicate that Southern Poland, and in particular the historical region of Galicia (which covers, inter alia, the area of the current Małopolska region), had been an agricultural land for centuries, with arable land accounting for $43.1 \%$ of the area of all farmlands in 1842 . During seven subsequent decades, the share of arable land increased by further 5.4\% at the expense of forests whose share decreased from $31.5 \%$ in 1842 to $25.7 \%$ in 1913 [Poławski 2009]. In the structure of land use in Southern Poland at the beginning of the $21^{\text {st }}$ century, the following can be distinguished: $36.8 \%$ of forests, $31.5 \%$ of arable land, $11.7 \%$ of meadows, $6.1 \%$ of pastures, $0.8 \%$ of orchards and gardens, and $13 \%$ of remaining farmlands [Angiel and Pietrzak 2009]. Studies confirm that in the second half of the last century there was a significant increase in the surface of forest areas, housing estates, and transport areas [Affek 2016, Starkel et al. 2007].

The $20^{\text {th }}$ century is called the age of urbanisation, which currently is among the most noticeable processes. At the beginning of the $20^{\text {th }}$ century, only $8 \%$ of the population worldwide still lived in towns and cities, with the remaining part living in villages. In mid- $20^{\text {th }}$ century, the percentage of urban population worldwide increased to $29 \%$ and in 1990 it amounted to $45 \%$, while in the $21^{\text {st }}$ century more people live in urban than in rural areas [Szymańska 2009]. The increase in the urban population and the development of urban pressure results in the establishment of large urban agglomerations, which take over increasingly greater areas of agricultural production space. Numerous studies confirm changes in land use, which take place in areas located in the immediate vicinity of cities [Bański 2008, Heffner 2015, Cegielska et al. 2017]. These areas are subject to increasing urban pressure, and this is where the suburbanisation phenomenon is most evident [Springer 2013]. What is more, peri-urban areas in Europe are growing four times faster than urban areas, and as Piorr et al. (2011) states, their total area of $48,000 \mathrm{~km}^{2}$ will be doubled in $30-50$ years.

In Europe, research into historical changes in land use is based inter alia on the cartographic part of the so-called Franciscan Cadastre [Harvey et al. 2014] established in the first half of the $19^{\text {th }}$ century for the Austrian Empire, and then for the AustroHungarian Empire [Lisek and Navratil 2014]. Cadastral maps covered the entire Austro-Hungarian Empire [Kain and Baigent 1992] with an area of more than 500,000 square kilometres [Krausmann 2003]. Cadastral maps provide opportunities for historical and geographical analyses of land use changes in many European countries, and they remain a detailed source of historical information about the landscape structure in the $19^{\text {th }}$ and $20^{\text {th }}$ centuries [Harvey et al. 2014].

Cadastral maps compiled for the area of Galicia were mainly scaled $1: 2880$, whereas in the case of big cities such as Kraków the scale $1: 1440$ was applied. A unit 
of measurement of the maps scaled $1: 2880$ was the Viennese fathom (in German: Klafter), whereas the Austrian morgen (in German: Joch) was the area unit (40 Austrian fathoms in the field were equal to 1 inch on the map). The content of cadastral maps is extremely detailed and precise, as it includes about 50 designations together with standards and colour scheme. Therefore, it can determine exactly the land cover (without topography), the land use and kind of development, the type of roads, the material used for the construction of architectural objects, the types of crops cultivated, and the type of forests i.e. everything that was significant for the amount of calculated taxes [Zachariasz 2012, Fuchs et al. 2015]. Historical analyses in these cases are possible because the appropriate and ample Austro-Hungarian cadastral maps were available, and because the taxation areal units delineated in these maps are similar or comparable to newer sources [Harvey et al. 2014].

Changes in land use are parallel to changes both in the potential of the environment - in Poland, the latter is defined as a reserve of natural resources with an appropriate structure and quality, which are available in a particular area - and in the stability of natural conditions determining the intensity of self-regulation of ecosystems and the resistance of the environment to anthropogenic pressure [The Act 2001].

In the article, we aim to analyse the direction of land use changes for two objects situated in the zones (one closer, and the other more distant) under the impact of Kraków, the capital city of the Małopolska region. The proposed method will enable the identification of the degree, rate, direction, and nature of these changes. We chose our study area with a view to examining to what extent changes in land use are determined by the proximity to the city of Kraków. Case study research at the local level is needed in order to foster a place-based culture. This local-level study is highly specific in its context (as it concerns peri-urban areas), the actors (developers, individuals - on the one hand, farm owners, on the other hand potential buyers who intend to buy a house, a service establishment, or a sales facility), the main processes (a conflict of interest at the interface of the city and countryside), and the scale of changes (which occur more rapidly following Poland's accession to the EU) [Bürgi et al. 2004, Fischer et al. 2011].

An analysis of the present-day land use structure against the historical data provides the data required for the assessment of the economic aspects of land use patterns, and it enables the identification of the need for possible changes in the spatial planning process [Kim and Pauleit 2007]. Research into land use changes in peri-urban areas can contribute to an assessment of the directions of future development in the vicinity of metropolitan cities.

\section{Material and methods}

\subsection{Study area}

The analysis of land use changes is presented using an example of two villages situated in the vicinity of the city of Kraków (Fig. 1). The villages selected for the analysis, namely Mogilany and Libertów, are located to the south of Kraków, in the municipal- 
ity of Mogilany. The villages were so selected for their location in the zones located increasingly further from the city.

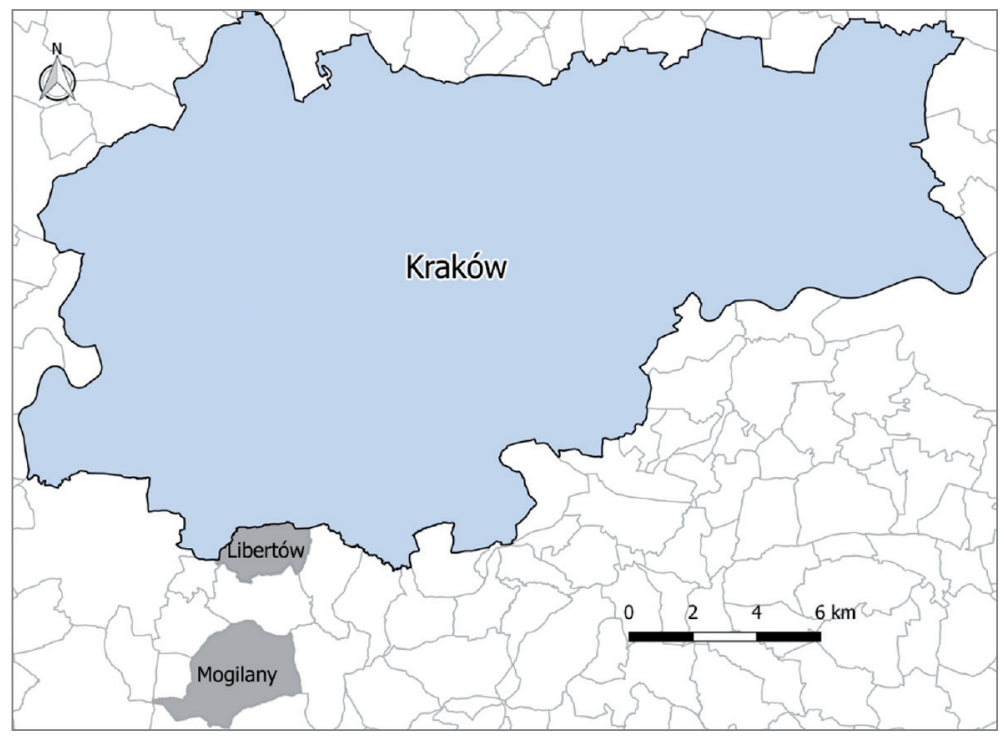

Source: Authors' own study

Fig. 1. Location of the case study objects Libertów and Mogilany relative to Kraków

The analysis involved the comparison of land use in the villages situated peripherally in relation to Kraków. The first of the analysed objects covered the cadastral municipality of Libertów. Currently, the village immediately neighbours the city of Kraków. According to a description from the nineteenth century, the village had been situated approx. $4.6 \mathrm{~km}$ away from Mogilany. According to the entries in the historical Dictionary, at the end of the nineteenth century, the village of Libertów covered the area of 709 morgens, and had the population of 550 people [Sulimierski et al. 1881].

The distance of the second study object, namely the village of Mogilany, from the current southern administrative boundaries of Kraków is $4 \mathrm{~km}$. According to nineteenth-century descriptions, this is one of the oldest settlements in Poland. At the end of the $19^{\text {th }}$ century, the distance from Kraków was $12 \mathrm{~km}$ as the crow flies. The population of Mogilany was 1397, and its area was 1394 morgens [Sulimierski et al. 1881].

In the study presented herein, a largely empirical but also a descriptive approach was followed. The main sources for reconstructing the land use and its history were the Franciscan cadastral maps compiled for the area of the former Austro-Hungarian Empire, and the Topographic Object Databases known as BDOT10k as of 2016. Among other things, BDOT10k includes in its content units of administrative division, transportation network, buildings (their location and functions), and complexes of land use. 
The research was carried out using the QGIS software and geoprocessing tools as well as data management tools (a combination of attributes according to the location). For the calculations of basic statistics in particular localities, the Group Stats plugin was used.

Table 1. The characteristics of the study objects in the second half of the $19^{\text {th }}$ century

\begin{tabular}{|c|c|c|}
\hline Village & Libertów & Mogilany \\
\hline Distance from Kraków & $\begin{array}{l}7.4 \mathrm{~km} \text { from Kraków (approx. } \\
4.6 \mathrm{~km} \text { away from Mogilany) }\end{array}$ & $\begin{array}{l}12 \mathrm{~km} \text { from Kraków as the } \\
\text { crow flies }\end{array}$ \\
\hline Population in 1880 & 550 & 1397 \\
\hline Area in morgens $(1$ morgen $=0.56 \mathrm{ha})$ & 709 morgens & 1394 morgens \\
\hline Location characteristics & on an undulating area & $\begin{array}{l}\text { on a hill with a height of } \\
396 \mathrm{~m} \text { ASL }\end{array}$ \\
\hline Area of farmland (in morgens) & $\begin{array}{l}498 \text { arable land } \\
112 \text { meadows and gardens } \\
50 \text { pastures } \\
49 \text { forests }\end{array}$ & $\begin{array}{l}883 \text { arable land } \\
167 \text { meadows and gardens } \\
135 \text { pastures } \\
209 \text { forests }\end{array}$ \\
\hline Number of houses & approx. 90 & approx. 230 \\
\hline
\end{tabular}

Source: Authors' own study based on Sulimierski et al. [1881]

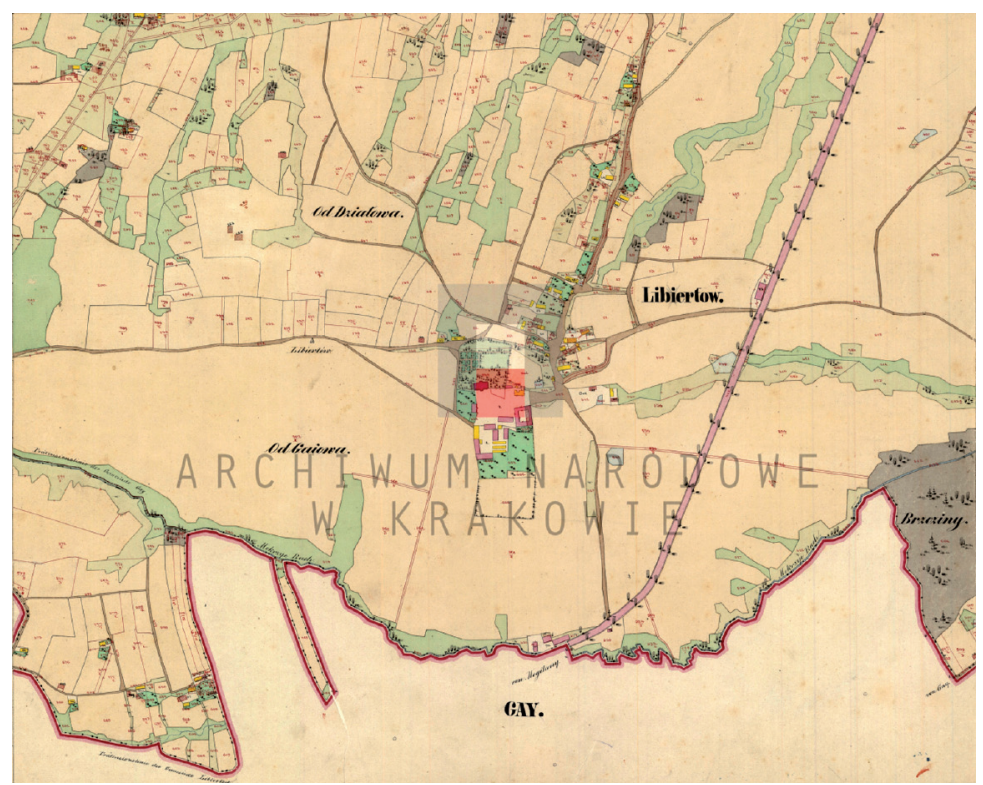

Source: National Archive in Krakow, https://szukajwarchiwach.pl/

Fig. 2. Map of Franciscan Cadastre, 156 Dorf Libiertów (Libertów) in Galizien Wadowicer Kreis, from the unit with the reference number 29/280/0/9.1/1195 
Historical data i.e. the scanned cadastral maps were made available by the National Archives in Kraków, and were accessed via the http://szukajwarchiwach.pl website. Maps were provided in file format .tif, with the resolution of 600 dpi. The original, historical map was manually drawn on a scale of 1 to 2880. The maps for Libertów and Mogilany were compiled in 1845.

The acquired scanned copies of cadastral maps for the analysed villages (see Fig. 2) were calibrated, then the target coordinate system was determined [ETRS 2180], and the parcels (land plots) were converted manually into vector format, with a number and the type of farmland determined for each of them. The definitions of the types of farmland (and the corresponding key) were adopted in accordance with the guidelines of the Instructions prepared for the purpose of compiling cadastral maps in the AustroHungarian Empire [Instructions 1824]. The differences in thematic classes between historical maps and BDOT10k were homogenised by simplifying all land uses into nine comparable categories of land use which include: built-up areas, forests, meadows, pastures, arable land, wasteland, roads, water areas, and orchards. The thematic consistency of land use categories is a crucial step in an analysis of long-term land use changes involving comparisons [Petit and Lambin 2002].

Two vector layers were obtained for each of the villages under analysis, which showed the status as of 1848 and 2016. Within the Libertów area, 705 objects (parcels) with a total area of 375.28 ha were vectorised. As regards Mogilany, 2670 objects with an area of 848.27 ha were subjected to vectorisation. Due to the low value of error, the noted discrepancies (between the course of administrative boundaries in the mid-19 century and the current status) have no significant impact on the results of the analysis. The layers thus developed were used for analyses, spatial inquiries, and matrix products.

Graphical spatial representations were created using binary change maps by highlighting those areas that had undergone changes from one period to another. A primary (qualitative) tool in the analysis of a time series of maps is a simple visual comparison. It can be complemented by a secondary tool, leading to the creation of new maps, which quantitatively highlight the changes that have occurred over time. For the specific time period, a binary change map was generated, which indicated the changes. Quantitative data relating to land-use surface areas were processed using the binary change index [e.g. van Eetvelde and Käyhkö 2009], which is obtained from the following formula:

$$
\mathrm{BCI}=\frac{\mathrm{NCH}-\mathrm{CH}}{\mathrm{NCH}+\mathrm{CH}}
$$

where $\mathrm{NCH} \%$ and $\mathrm{CH} \%$ represent the areas which remained unchanged and changed, respectively, during the studied period. The binary change index varies linearly, and its indices range from -1 (radical change) to +1 (no change) [Pătru-Stupariu et al. 2011]. 


\section{Results and discussion}

The spatial analysis demonstrated that all the villages under analysis in the mid- $19^{\text {th }}$ century were typically agricultural areas. We were able to confirm that land cultivation was a part of the culture of this region [Poławski 2009]. The farmlands were an essential component of land cover, and their share amounted to $88.4 \%$ for Libertów, $80.3 \%$ for Mogilany (Fig. 3). The areas under wooden buildings in the $19^{\text {th }}$ century covered a small surface i.e. approx. $0.8 \%$ in all villages under analysis (Fig. 3 - on the left side).

1845

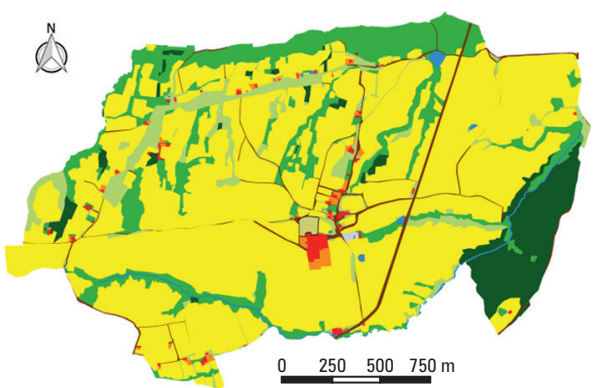

Object 1 (Libertów )

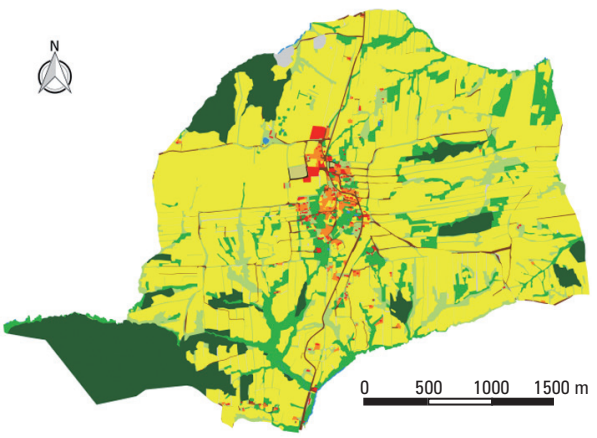

Object 2 (Mogilany)

Land use description

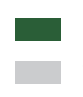

Pastures

Arable lands
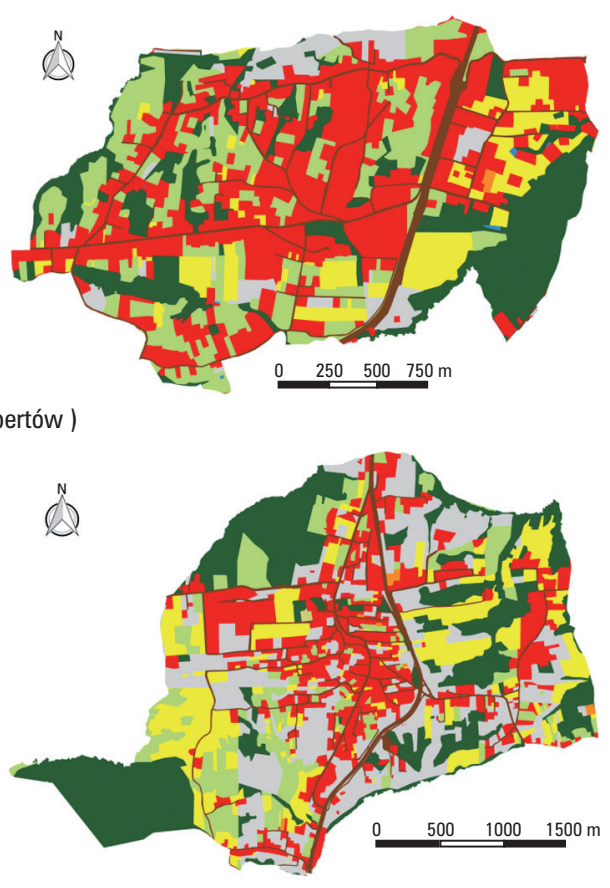

Waters

Build-up areas

Source: Authors' own study

Fig. 3. Transition maps of land-use changes in the studied objects of Libertów and Mogilany between the mid- $19^{\text {th }}$ century and 2016

Having carried out an assessment of the general direction of changes during the period of 1845-2016 in the analysed villages, we were able to conclude that they have lost their agricultural nature after having been subjected to significant changes in land use. Currently, the farmlands (arable land and grassland) only account for $30.4 \%$ of the 


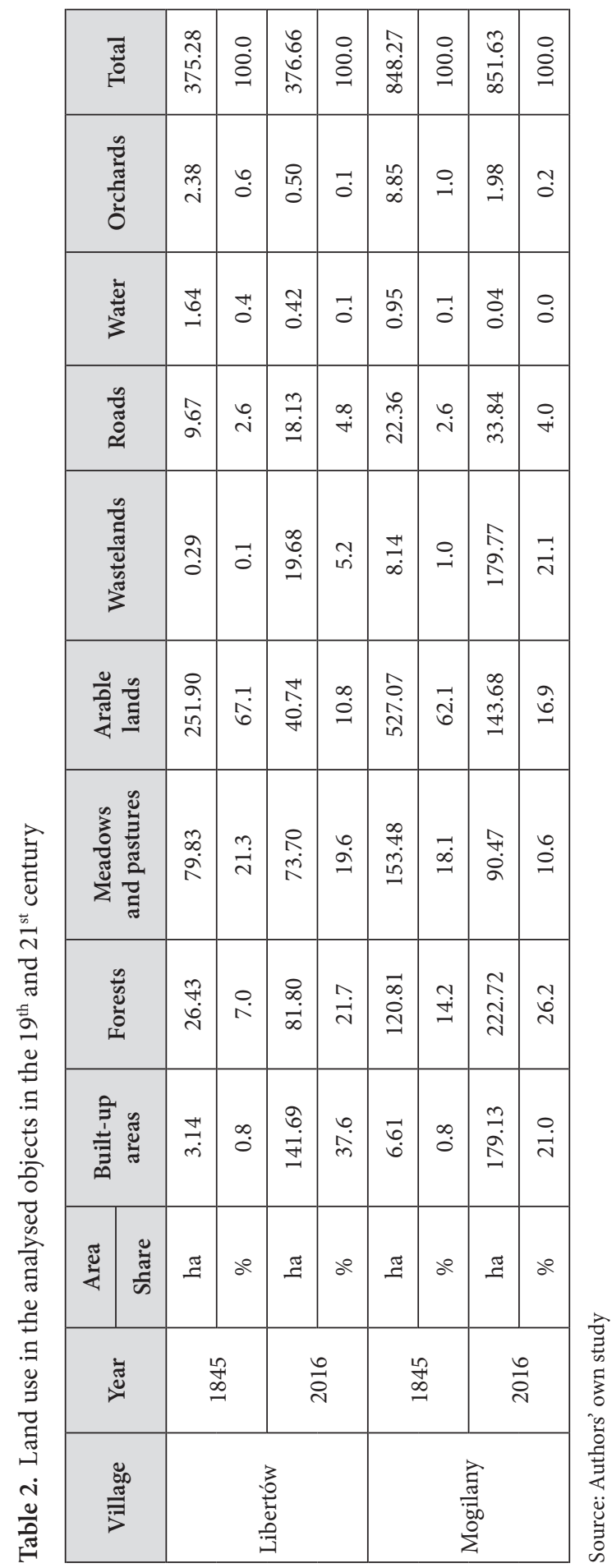


total area in Libertów, and for 27.5\% in Mogilany (Table 2). The difference in the area of farmland, calculated between the mid-19 $9^{\text {th }}$ century and the current status (2016), amounts to $58.0 \%$ for Libertów, and $52.7 \%$ for Mogilany. At present, within the area of the analysed villages, built-up areas have a significant share (see Fig. 3, Table 2), and these percentages range from $21.0 \%$ for Mogilany to as much as $37.6 \%$ for Libertów. In the area under analysis, the percentage of forests increased to $21.7 \%$ in Libertów, and to $26.2 \%$ in Mogilany. Changes in land use are also noticeable for roads and wasteland. The percentage of wasteland increased significantly in Mogilany - from 1\% in the mid$19^{\text {th }}$ century to $21.1 \%$ in 2016 ; whereas in Libertów, the area of wasteland increased by $5.1 \%$. Having analysed changes in land use within the studied objects, we noticed that changes did not occur in a uniform way, which is clearly visible during a comparative analysis of land use maps from the periods under study for the built-up areas.

In the first of the analysed objects (Libertów), changes affected a large part of the village, and the built-up areas occupied the space on both sides of roads. The second object (Mogilany) is also an area of extensive changes, but the housing development has taken a more fragmented form, as the individual changes are smaller in terms of the surface area (Fig. 4).
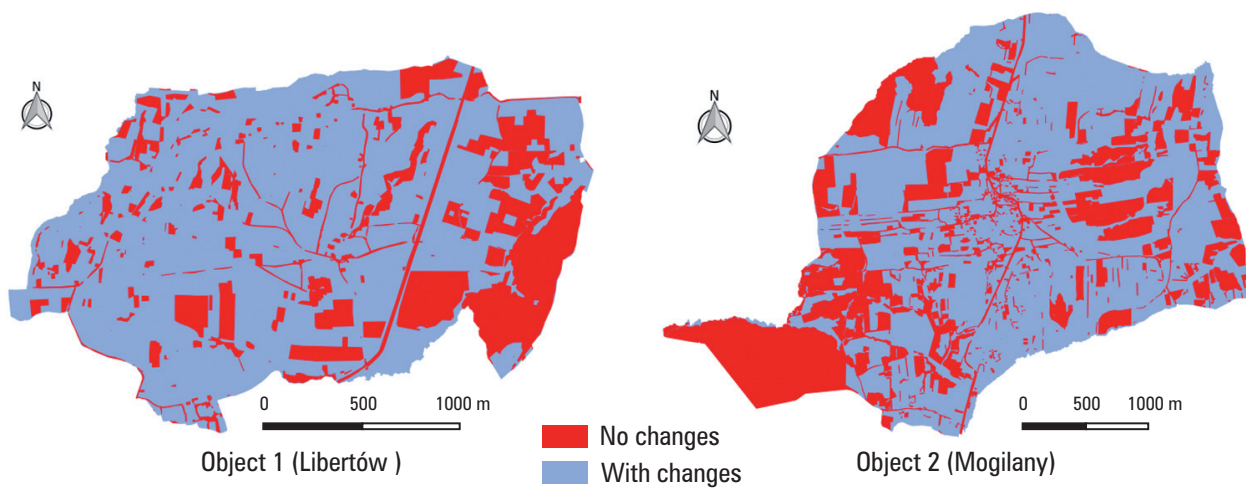

Source: Authors' own study

Fig. 4. Binary maps of land use changes in Libertów and Mogilany between 1845 and 2016

During the period under study, very dynamic changes were observed in the land use of the analysed objects, which is represented in the developed binary change maps (see Fig. 4, blue colour indicates the land use changes). Changes in land use covered an area of $77 \%$ of Libertów, and $70 \%$ of Mogilany. Binary change index for Libertów takes value of -0.542 . This parameter calculated for Mogilany amounts to -0.396 . This confirms that great changes in land use occurred in the area of Libertów i.e. the village located closest to the city of Kraków. Significant changes were also noted in the Mogilany area, located approx. $6 \mathrm{~km}$ away from Kraków towards the south. The highest rate of change for the analysed objects occurred within the area size of arable land and grassland (see 
Fig. 5). In Libertów, more than $20 \%$ of arable land was converted into built-up areas, while over $10 \%$ turned into wasteland.

A similar situation occurred in Mogilany, as arable land was converted, inter alia, into built-up areas (over 10\%) or grassland (over 10\%) (Fig. 5).
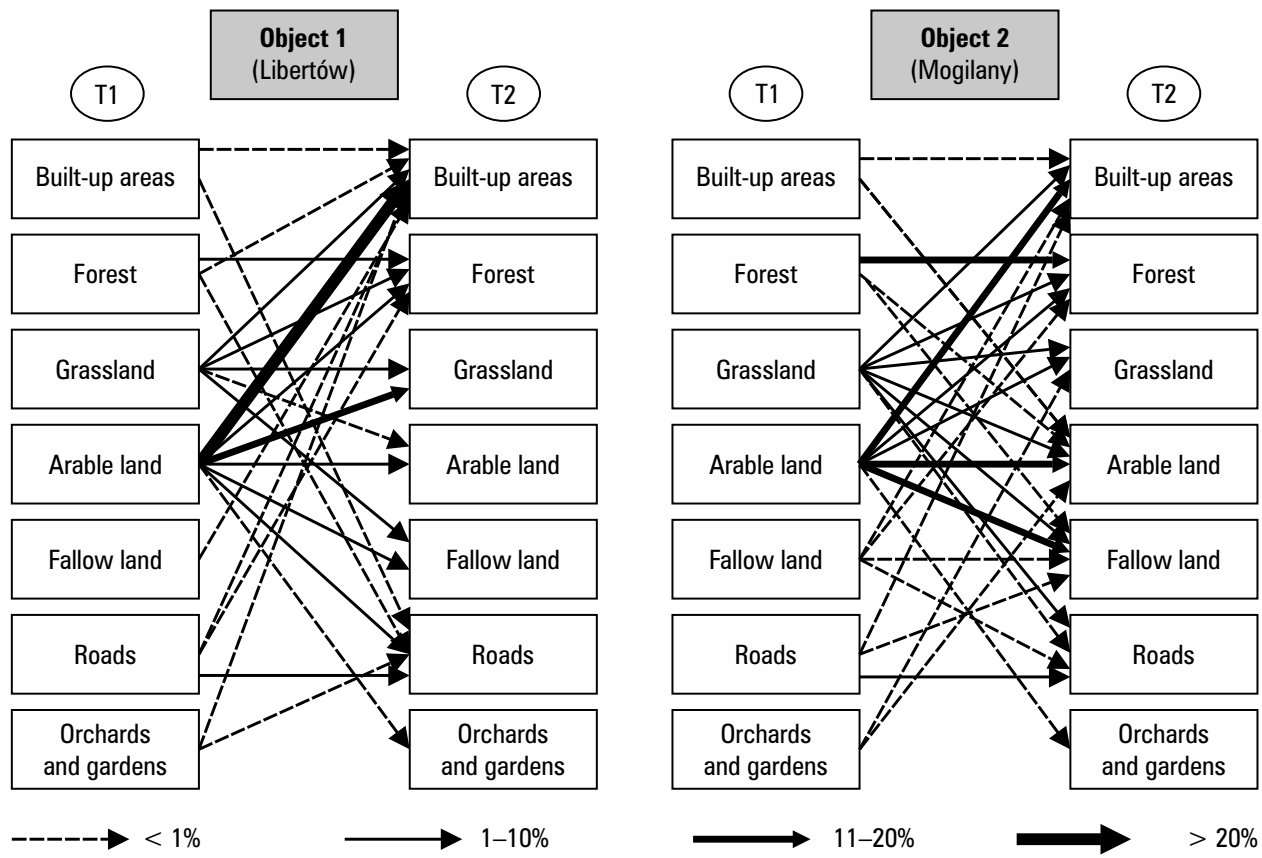

Source: Authors' own study

Fig. 5. Directions of land use changes in the analysed objects from the years 1845 (T1) and 2016 (T2). The range of changes is represented by different arrow thicknesses

Historical changes in land use in Southern Poland are typified by varying level of activity. Due to the fact that this region used to be an area with a low economic potential and very high population density, changes in the land use over the $19^{\text {th }}$ century and in the following years proceeded very slowly. After the Second World War, during the Communist era, the use of land did not change dynamically either due to the low level of nationalisation of agricultural farms, or the low percentage of accumulated land in Southern Poland [Bański 2008, Poławski 2009, Affek 2016]. In the new socioeconomic reality post 1989, the agricultural area came under pressure from other sectors of the economy that were in need of new land for development [Bański 2017]. Since the time of political transformations in Poland and its accession to the European Union, changes in land use have also progressed very dynamically.

The process of changes and the land use conversion is clearly visible in agricultural areas directly adjacent to cities. This study states that the main cause of the consump- 
tion of agricultural land in peri-urban areas in Southern Poland is the urban growth. As confirmed by Mazzocchi et al. [2013], this is the main cause of the agricultural land consumption in recent years in Europe. It is confirmed that a peri-urban area usually experiences intense urban development where agriculture, small-scale industry, industrial estates and suburban residential developments co-exist side by side [Samat et al. 2011, McGee 2011]. This particular area, therefore, has access to essential and complimentary linkages between the urban and rural zones, since the income sources for the livelihood of its community come from the combination of agriculture and non-agricultural sectors [Tacoli 1998, Carrion-Flores and Irwin 2004, Kombe 2005]. Some authors state that land use changes in the peri-urban area constitute a complex and dynamic process that involves both natural and anthropogenic systems [Xiao et al. 2006, Koomen and Stillwell 2007]. The authors mainly confirm that the closer the proximity of agricultural land to cities, the bigger the urban pressure on the farm property [Bell and Irwin 2002, Huang et al. 2006, Corpade et al. 2014, Indrova and Kupkova 2015].

This is indicated inter alia by the value of the binary change index, which is recorded at a very high or high level for the analysed villages.

Undeniably, changes occur more rapidly in villages immediately neighbouring the city of Kraków (i.e. the object of Libertów). The distance from the city is an important factor that affects the process of suburbanisation, which is confirmed inter alia by a study conducted in the suburbs of Tallinn in Estonia [Tammaru 2009]. However, the changes were also noted in a zone located further away from Kraków (the objects Mogilany). It is evident that Kraków has a strong impact on the land use towards the south. Here, as in the case of other large urban agglomerations, the dynamics of suburbanisation process have aggressively penetrated into the environment of rural areas, which is confirmed inter alia by studies conducted by Zimnicka and Czernik [2007] in a peripheral zone of the city of Szczecin, or by Głaz [2006] in a suburban zone of the city of Wrocław. The most dynamically developing element of the space is the built-up areas whose area increases at the expense of areas used for agricultural purposes.

In addition, it was found that the close proximity to Kraków contributed to agricultural marginalisation i.e. a process as a result of which the agricultural activity pursued so far is no longer profitable [Baldock et al. 1996]. The villages located closer to Krakow have a greater share of wastelands than the areas located further away from the urban agglomeration, even though the land located there is highly valuable and suitable to farming. An important argument for the occurring changes may be the shift in the employment structure of the local inhabitants, which changed following the political transformation in 1989; currently, inhabitants of villages adjacent to Kraków mainly support themselves with non-agricultural sources of income.

The villages of Libertów and Mogilany have lost their agricultural and forest functions. The greatest transformations in the studied objects occurred in the surface area of arable land. In the suburbs of the city of Tallinn, farmland has also been replaced by built-up areas [Tammaru et al. 2009]. However, no trends were observed there towards an increase in large areas of wasteland on which agricultural activity has been discontinued, as is the case for the analysed villages located in proximity to Kraków. 
In this case, the increase in the area of wasteland is not related to the loss of property rights but only to a decrease in profitability of agricultural production in favour of nonagricultural sources of income.

The urban pressure on the areas adjacent to the city primarily manifests in the occupation of areas hitherto used for agricultural purposes by large-sized development i.e. warehouses as well as industrial facilities.

An analysis of the present-day land use structure against the historical changes and natural conditions provides the data required to assess the economic aspects of land use patterns, and enables the identification of a need for possible changes in the spatial planning process [Kim and Pauleit 2007]. The presented analyses may be helpful for harmonious development of urban areas, and for the preservation of arable land and the environment.

Not only did the proposed method enable the identification of the magnitude of land use changes, but it also revealed their rate and nature. The main directions of changes concerned conversions of a natural and anthropogenic nature, with the anthropogenic changes having a wider range than the natural ones.

\section{Conclusions}

The presentation of historical land use changes in peri-urban areas showed that the distance to major urban settlements is an important factor that affects the rate of transformations of the landscape of rural areas. Land use conversions do not occur in a uniform way in each case study. Farmland in the suburbs is converted into built-up areas, which results in a decrease in the potential of the natural environment as well as in agricultural marginalisation (abandonment of agricultural production). In the village of Libertów immediately adjacent to the city of Kraków from the south, $25 \%$ of arable land has been converted into wasteland.

The identification of the direction of land use changes along with the determination of their dynamics is a significant element supporting sound management of the space. This task requires information on land use (and its changes) as well as on the scale, the level of detail, and the time horizon adjusted to the specificity of the task at hand. Therefore, the system of land use management should be addressed with the view to reconciling contradictions of diverse development planning, and formulating a set of rules in order to maintain the sustainable development of rural regions.

The study presented in this paper was supported by the DS 3371/KGPiAK/2019 research project, financed from a specific grant provided by Minister of Science and Higher Education.

\section{References}

Affek A. 2016. Dynamika krajobrazu. Uwarunkowania i prawidłowości na przykładzie dorzecza Wiaru w Karpatach (XVIII-XXI w.). Prace Geograficzne, 251, Instytut Geografii i Przestrzennego Zagospodarowania PAN, Warszawa. 
Angiel M., Pietrzak M. 2009. Wieś tradycyjna w krajobrazie Pogórzy Karpackich. Prace Komisji Krajobrazu Kulturowego, 12. Polskie Krajobrazy Dawne i Współczesne. Komisja Krajobrazu Kulturowego PTG, Sosnowiec.

Antrop M. 2005. Why Landscapes of the Past are Important for the Future. Landscape and Urban Planning, 70 (1-2), 21-34, DOI: 10.1016/j.landurbplan.2003.10.002

Baldock D., Beaufoy G., Brouwer F., Godeschalk F. 1996. Farming at the margins: Abandonment of redeployment of agricultural land in Europe. Institute for European Environmental Policy (IEEP), Agricultural Economics Research Institute, London/The Hague.

Bański J. 2008. Strefa podmiejska - już nie miasto, jeszcze nie wieś. [W:] Gospodarka przestrzenna w strefie kontinuum miejsko-wiejskiego w Polsce. Red. A. Jezierska-Thöle, L. Kozłowski. Wyd. Naukowe Uniwersytetu Mikołaja Kopernika, Toruń, 29-43.

Bański J. 2017. The consequences of changes of ownership for agricultural land use in Central European countries following the collapse of the Eastern Bloc. Land Use Policy, 66, 120-130.

Bell K.P., Irwin E.G. 2002. Spatially explicit micro-level modeling of land use change at the rural-urban intereface. Agricultural Economics, 27, 217-232.

Bürgi M., Hersperger A., Schneeberger N. 2004. Driving forces of landscape change - current and new directions. Landscape Ecology, 22 (Supl. 1), 77-87.

Bürgi M., Straub A., Gimmi U., Salzman D. 2010. The recent landscape history of Limpach valley, Switzerland: Considering three empirical hypotheses on driving forces of landscape change. Landsc. Ecol., 25, 287-297.

Carrion-Flores C., Irwin E. 2004. Determinants of residential land-use conversion and sprawl at the rural urban fringe. American Journal of Agricultural Economics, 86 (4), 889-904.

Cegielska K., Salata T., Gawroński K., Różycka-Czas R. 2017. Level of Spatial Differentiation of Anthropogenic Impact in Małopolska. Journal of Ecological Engineering, 18, 1, 200-209.

Corpade C., Man T., Petrea D., Corpade A.M., and Moldovan C. 2014. Changes in landscape structure induced by transportation projects in Cluj-Napoca periurban area using GIS. Carpathian Journal of Earth and Environmental Sciences, 9 (4), 177-184.

Domon G., Bouchard A. 2007. The landscape history of godmanchester (Quebec, Canada): Two centuries of shifting relationships between anthropic and biophysical factors. Landsc. Ecol., 22, 1201-1214.

Fuchs R., Verburg P.H., Clevers J.G.P.W, Herold M. 2015. The potential of old maps and encyclopaedias for reconstructing historic European land cover/use change. Applied Geography, $59,43-55$.

Głaz M. 2006. Przekształcenia agrarne strefy podmiejskiej jako efekt oddziaływania miasta Wrocławia. [W:] Przemiany przestrzeni miast i stref podmiejskich. Red. J. Słodczyk, R. Klimek. Uniwersytet Opolski, Opole, 153-166.

Harvey F., Kaim D., Gajda A. 2014. Analysis of historical change using cadastral materials in the Carpathian Foothills. European Journal of Geography, 5, 3, 6-21.

Heffner K. 2015. Przestrzeń jako uwarunkowanie rozwoju obszarów wiejskich w Polsce. Wieś i Rolnictwo, 2 (167), 83-103.

Hersperger A.M., Bürgi M. 2009. Going beyond landscape change description: Quantifying the importance of driving forces of landscape change in a Central Europe case study. Land Use Policy, 26, 640-648.

Indrova M., Kupková L. 2015. Land Use Changes in Prague Suburban Area According to Different Prediction Modelling Approaches. Geografie, 120, 3, 422-443.

Instructions 1824. Instruktion zur Ausführung der zum Berufe des allgemeinen Katasters in Folge des 8. und 9. Paragraphen des Allerhöchstens Patentes vom 23. Dezember 1817 angeordneten Landesvermessung. Wien 1824. 
Kain R., Baigent E. 1992. The cadastral map in the service of the state - a history of property mapping. University of Chicago, Chicago.

Kim K.H., Pauleit S. 2007. Landscape character, biodiversity and land use planning: Case of Kwangju City Region, South Corea. Land Use Policy, 24, 264-274.

Kombe W.J. 2005. Land use dynamics in peri-urban areas and their implications on the urban growth and form: The case of Dar es Salaam, Tanzania. Habitat International, 29, 113-135. http://dx.doi.org/10.1016/S0197-3975(03)00076-6

Koomen E., Stillwell J. 2007. Modelling land use change: Theories and methods. [In:] Modelling Land-Use Change: Progress and Application. Eds. E. Koomen, J. Stillwell, A. Bakema, H. Scholten. Springer, Dordrecht, The Netherlands, 1-21.

Krausmann F. 2003. Land Use and Societal Metabolism in $19^{\text {th }}$ Century Austrian Villages: The Franziscean Cadastre as a source for modeling pre-industrial land use systems in Central Europe. [In:] Dealing with diversity, $2^{\text {nd }}$ International Conference of the European Society for Environmental History, Proceedings. Eds. L. Jeleček, P. Chromý, H. Janů, J. Miškovský, L. Uhlířová. Prague, 237-242.

Lambin E.F., Geist H. 2006. Land-Use and Land-Cover Change. Local Processes and Global Impacts. Springer, Heidelberg.

Lisec A., Navratil G. 2014. The Austrian Land Cadastre: from the earliest beginnings to the modern land information system. Geodetski Vestnik, 58, 3, 482-499.

Liu X., Wang Y., Li Y., Liu F., Shen J., Wang J., Xiao R., Wu J. 2017. Changes in arable land in response to township urbanization in a Chinese low hilly region: Scale effects and spatial interactions. Applied Geography, 88, 24-37.

Mazzocchi C., Sali G., Corsi S. 2013. Land use conversion in metropolitan areas and the permanence of agriculture: Sensitivity Index of Agricultural Land (SIAL), a tool for territorial analysis. Land Use Policy, 35, 155-162.

McGee T. 2011. Rethinking the urban fringe in Southeast Asia, Policy and Research Agendas. Paper presented at the workshop on Issues in the Peri-Urban Regions and Ways towards Sustainable Peri-Urban Futures.

National Archives in Kraków - map scans - '176 Dorf Mogilany samt Enclave Kulerzow in Galizien Wadowicer Kreis' - signature 29/280/0/9.1/1245'; '156 Dorf Libiertow in Galizien Wadowicer Kreis' - signature 29/280/0/9.1/1195'; '314 Włosań in Galizien Wadowizer Kreis' - signature 29/280/0/9.1/1554; '66 Dorf Gay in Galizien Wadowizer Kreis' - signature 29/280/0/9.1/1042.

Pătru-Stupariu I., Stupariu M.S., Cuculici R., Huzui A. 2011. Understanding landscape change using historical maps. Case study Sinaia, Romania. Journal of Maps, 7 (1), 206-220.

Petit C.C., Lambin E.F. 2002. Impact of data integration technique on historical land use/land-cover change: Comparing historical maps with remote sensing data in the Belgian Ardennes. Landscape Ecology, 17, 117-132.

Poławski Z.F. 2009. Zmiany użytkowania ziemi w Polsce w ostatnich dwóch stuleciach (Land use changes in Poland during last two centuries). Teledetekcja Środowiska, 42, 69-82.

Piorr A., Ravetz J., Tosics I. 2011. Peri-urbanisation in Europe: Towards a European Policy to Sustain Urban-Rural Futures. University of Copenhagen, Academic Books Life Sciences, 144.

Robinson B.E., Holland M.B., Naughton-Treves L. 2014. Does secure land tenure save forests? A meta-analysis of the relationship between land tenure and tropical deforestation. Global Environmental Change, 29, 281-293.

Regulation 1972. Rozporządzenie Rady Ministrów z dnia 30 listopada 1972 r. w sprawie zmiany granic miasta Krakowa, Poznania i Wrocławia. Dz. U. z 1972 r. Nr 50, poz. 323. 
Samat N., Hasni R., Elhadary Y.A.E. 2011. Modelling land use changes at the peri-urban areas using geographic information systems and cellular automata model. Journal of Sustainable Development, 4(6), 72-84. http://dx.doi.org/10.5539/ jsd.v4n6p72.

Seto K.C., Fragkias M., Güneralp B., Reilly M.K. 2011. A meta-analysis of global urban land expansion. PLoS One 6, e23777.

Springer F. 2013. Wanna z kolumnadą. Wyd. Czarne, Warszawa.

Sulimierski F., Chlebowski B., Walewski W. (red.) 1881. Słownik geograficzny Królestwa Polskiego i innych krajów słowiańskich. T. III, 902: Kaszów, T. V, 202-203: Libertów, T. VI, 579-580: Mogilany, T. X, 876: Śmierdząca.

Starkel L., Pietrzak M., Łajczak A. 2007. Wpływ zmian użytkowania ziemi i wzrostu częstotliwości ekstremalnych opadów na obieg wody i erozję oraz ochronę zasobów przyrodniczych Karpat. Problemy Zagospodarowania Ziem Górskich, 54, 19-30.

Szymańska D. 2009. Geografia osadnictwa. Wyd. PWN, Warszawa.

Tacoli C. 1998. Rural-Urban interaction: A guide to the literature. Environment and Urbanization, 10 (1), 147-166.

Tammaru T., Leetmaa K., Silm S., Ahas R. 2009. Temporal and spatial dynamics of the new residential areas around Tallinn. European Planning Studies, 17 (3), 423-439.

The Act 2001. Ustawa z dnia 27 kwietnia 2001 r. - Prawo ochrony środowiska (Dz. U. Nr 62, poz. 627 z 2007 r. z późn. zmianami).

Van Asselen S., Verburg P.H., Vermaat J.E., Janse J.H. 2013. Drivers of wetland conversion: A global meta-analysis. PLoS One 8, e81292.

Van Eetvelde V., Käyhkö N. 2009. The applicability of quantitative techniques for assessing spatio-temporal patterns of landscape changes. [In:] Proceedings of the European IALE Conference. Eds. J. Breuste, M. Kozová, M. Finka, 379-382.

Van Vliet J., Verburg P.H., Magoliocca N., Ellis E.C., Buchner B., Cook E., Rey Benayas J., Heinimann A., Keys E., Lee T., Liu J., Mertz O., Meyfroidt P., Moritz M., Robinson B., Seppelt R. 2015. Meta-studies in land use science current coverage and prospects. Ambio, 45, 15-28.

Xiao J., Shen Y., Ge J., Tateishi R., Tang C., Liang Y. 2006. Evaluating urban expansion and land use change in Shijiazhuang, China by using GIS and remote sensing. Landscape and Urban Planning. 75, 69-80. http://dx.doi.org/10.1016/j.landurbplan.2004.12.005

Zachariasz A. 2012. Przydatność archiwalnych źródeł kartograficznych dla współczesnych badań krajobrazowych. [W:] Źródła kartograficzne w badaniach krajobrazu kulturowego. Prace Komisji Krajobrazu Kulturowego, 16, Sosnowiec, 63-83.

Zimnicka A., Czernik L. 2007. Kształtowanie przestrzeni wsi podmiejskiej. Raport z badań obszaru oddziaływania miasta Szczecina. Instytut Architektury i Planowania Przestrzennego, Politechnika Szczecińska, Szczecin.

Dr hab. inż. Barbara Prus

Uniwersytet Rolniczy w Krakowie

Wydział Inżynierii Środowiska i Geodezji

Katedra Gospodarki Przestrzennej i Architektury Krajobrazu

ul. Balicka 253c, 30-198 Kraków

e-mail: barbara.prus@urk.edu.pl

Mgr inż. Arkadiusz Nowak

Absolwent Wydziału Inżynierii Środowiska i Geodezji

Uniwersytetu Rolniczego w Krakowie 